\title{
Anatomical Structure and Terpenoid Content of Zodia (Evodia suaveolens Scheff) Leaves
}

\author{
Evi Mintowati Kuntorini ${ }^{1,{ }^{*}}$, Dewi Nofaliana ${ }^{1}$, and Eny Dwi Pujawati ${ }^{1}$ \\ ${ }^{1}$ Biology Department, Faculty of Mathematics and Natural Sciences, Universitas Lambung Mangkurat. \\ Jl. A. Yani Km 36 Banjarbaru, South Kalimantan, Indonesia.
}

\begin{abstract}
Zodia (Evodia suaveolens Scheff) is a member of Rutaceae contain terpenoids, triterpenoids, alkaloids, flavonoids, and xanthones which have anti-mosquito activity. This research aimed to observe the anatomical structure, the location, and distribution of terpenoid based on the leaves' age. Anatomical slides preparation of leaves were made using the paraffin embedding method with safranin staining. The distribution of terpenoid was analyzed by the histochemical assay. Leaf anatomical structure shows that the $3^{\text {rd }}$ and $6^{\text {th }}$ leaf bifacial (dorsiventral) consisted of the upper epidermis, mesophyll (palisade and sponge), collateral vascular bundle, parenchyma midrib, abaxial epidermis and oil glands in mesophyll that is underneath both epidermises. The diameter of oil glands with larger sizes was on the $6^{\text {th }}$ leaf, whereas the density is not different in the $3^{\text {rd }}$ and $6^{\text {th }}$ leaves. The histochemical test showed that terpenoid was observed in the leaf vascular bundles, oil glands, and epidermis.
\end{abstract}

\section{Introduction}

Zodia (Evodia suaveolens Scheff) family Rutaceae, contain anti-mosquito terpenoids [1], triterpenoids [2], alkaloids [3], flavonoids, and xanthon [4]. Anti-mosquito compounds include essential oils Linalool [5], as well as alkaloid evodiamine [6] and rutaecarpine [7]. One of the mosquitoes types that must be controlled is Aedes aegypti. Linalool compounds in zodia plants as a mosquito repellent. $[7,8,9,4]$.

Essential oils have benefits for cosmetic raw materials, for example, perfume and lotion [10,11]. The Indonesian Ministry of Agriculture (2006) has determined that E. suaveolens is included in the list of target plants which is classified as biopharma commodities (useful for medicines, health, and cosmetics purposes).

E. suaveolens woody plants (shrubs) can also be as an ornamental plant, which is originally from Papua. Indigenous Papuans have used leaves as a mosquito repellent by rubbing on the hands and feet [9].

E. suaveolens leaf has a distinctive aroma and is used by the community in the forest as an anti-mosquito, therefore it is necessary to observe the anatomical structure of the leaves of E. suaveolens to see the oil glands that contain essential oil compounds.

\section{Materials and Methods}

\subsection{Plant materials}

The materials used were the 3rd (young leave) and 6th (old leave) leaves from the tip stem of Zodia collected from our collection. Three replicate samples of leaves were taken from three different individual plants. The sample plant identification was done by Herbarium Bogoriense, Indonesian Institute of Sciences, Bogor, Indonesia.

\subsection{Anatomical slides preparation}

For permanent anatomical slides, the leaves transverse sections were prepared using paraffin embedding method; and safranin staining, according to the procedure of [12] with slight modifications. The leaves were fixed in FAA (40\% Formalin: Glacial acetic acid: 70\% Alcohol; 5:5:90 ) solution for 24 hours. Dehydration was done by soaking the samples in the alcohol with $70 \%, 80 \%, 95 \%$ concentrations, each for 30 minutes. De-alcoholization was done by immersing the samples in alcohol: xylol with a ratio of $3: 1,1: 1,1: 3$, and xylol 100\% I and xylol $100 \% \mathrm{II}$, each for $30 \mathrm{~min}$. The sample was immersed in a solution of xylol II, an infiltration process was then performed with paraffin: xylol $(9: 1)$ at $57^{\circ} \mathrm{C}$ temperature for 24 hours. The mixture of paraffin: xylol was replaced with pure paraffin at a fixed $57^{\circ} \mathrm{C}$ temperature for 24 hours. The sample was blocked in pure paraffin. The paraffin which contains a sample was then sliced using a rotary microtome with $20 \mu \mathrm{m}$ thickness. The sample sections were stained using safranin.

\subsection{Histochemical assay}

The histochemical assay enables the identification and localization of specific substances within tissues. The methods depend on chemical reactions between the substance identified and its localization in a tissue section, and one or more reagents in which the tissue section is incubated. The histochemist tries to arrange matters so that the end product of the chemical reaction is both colored and insoluble, and therefore easily visible on microscopy [13].

The cellular distribution of terpenoid in plants can be observed using a histochemical method according to [14] with slight modifications. The leaves samples were thinly sliced using a hand microtome and razor blades. The thin transverse sections of leaves were then immersed for 24 hours in $5 \%$ copper acetate. After that,

* Corresponding author: evimintowati@ulm.ac.id 
the sections of the sample were then covered with glycerol and observed under a microscope. Brownishyellow color formation indicated a positive result for the terpenoid compound.

\subsection{Data analysis}

The qualitative anatomical and terpenoid content data obtained were analyzed descriptively. The quantitative data of the glandular cells density, in the $3^{\text {rd }}$ and $6^{\text {th }}$ leaves, were analyzed by t-test.

\section{Result and discussion}

\subsection{Anatomical structure}

Anatomical studies are critical to know the structure of the organ, the cells, and the tissues that are possible to synthesize secondary metabolite compounds [15].

The cross-section structures of the $3^{\text {rd }}$ and $6^{\text {th }}$ leaves showed almost the same in the anatomical structure. They consisted of upper (adaxial) and lower (abaxial) epidermises, as well as. The parasitic type of stomata. The number of stomata in the lower epidermal is relatively more than the upper one.

The leaf mesophyll of E. suaveolens is the dorsiventral or bifacial type, consists of palisade and sponge. Palisade parenchymal tissue is located one layer below the upper epidermis with long shape. Sponge tissue 5-6 hollow layers, irregular hexagonal shape, located under the palisade.

The oil glands in mesophyll are globular and underneath both epidermis (Figure 1A and B). This structure is larger than mesophylls, but the size is very prominent and almost half of the leaf cross-section. The shape of the leaf oil glands of E. suaveolens is similar to the leaves of Eucalyptus polybractea [16].

According to [17], the structure of secretion glands is also called an idioblast. The secretion cells have an elongated or larger size, so it is called a tube or sac. The secretion cell is larger than the parenchyma, located in the base parenchyma, as well as the vascular bundles of leaves and stems.

Vascular bundles consist of xylem and phloem of the collateral type. Sclerenchyma is on the outside of the vascular bundles. The oil glands in the upper and lower sections of the midrib (Figure 2).

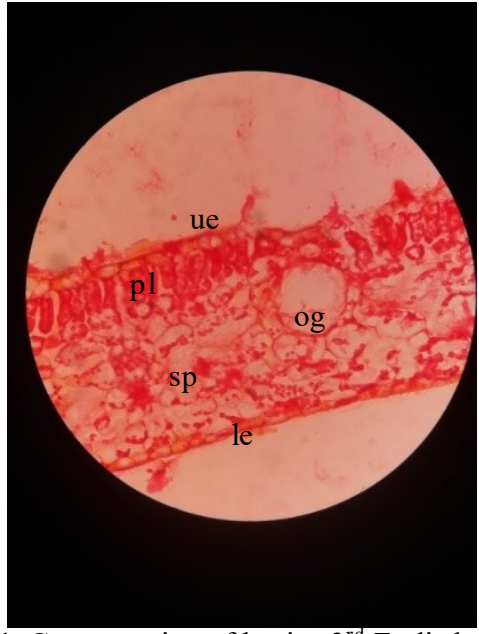

Figure 1. Cross-section of lamina $3^{\text {rd }}$ Zodia leaves, at a magnification of $x 400$. Notes: upper epidermis (ue), palisade (pl), sponge (sp), abaxial epidermis (le), Oil gland (og).

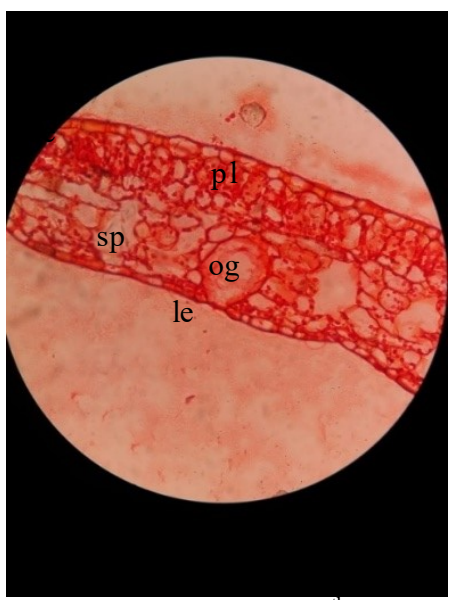

Figure 2. Cross-section of lamina $6^{\text {th }}$ zodia leaves, at a magnification of $x 400$. Notes: upper epidermis (ue), palisade (pl), sponge (sp), abaxial epidermis (le), Oil gland (og).

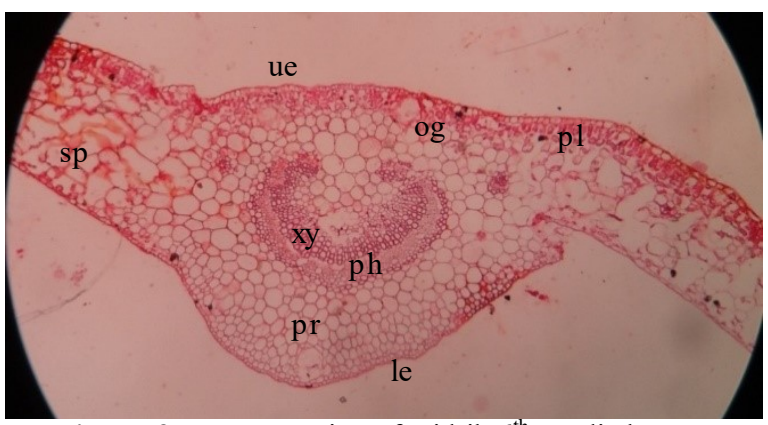

Figure 3. Cross-section of midrib $6^{\text {th }}$ Zodia leaves, at a magnification of $x 100$. Note : upper epidermis (ue), palisade $\mathrm{pl}$ ), sponge (sp), phloem (ph), xylem (xy), abaxial epidermis

(le), parenchyma (pr), oil gland (og).

Table 1. Diameter and density of oil glands in the 3rd and 6th leaves of E. suaveolens

\begin{tabular}{lcc}
\hline Leaf Sample & Diameter $(\mu \mathrm{m})$ & Density $\left(\mathrm{mm}^{2}\right)$ \\
\hline 3rd & 67.5 & 1.3 \\
6th & 77.5 & 1.2 \\
\hline
\end{tabular}


The diameter of the oil glands in the $3^{\text {rd }}$ leaf $(67.5$ $\mu \mathrm{m})$ is smaller than the $6^{\text {th }}(77.5 \mu \mathrm{m})$. Oil gland density has almost the same value on the $3^{\text {rd }}$ leaf $\left(1.3 / \mathrm{mm}^{2}\right)$ and the $6^{\text {th }}\left(1.2 / \mathrm{mm}^{2}\right)$ (Table 1$)$.

According to [18], plant growth is shown by increasing size, because multicellular organisms grow from zygotes. Consequently, it increases in volume, weight, number of cells, number of protoplasms, and level of complexity. The process of growth and development, both are the resulting in 3 simple stages at the cellular level. First, the cell division stage, adult cells divide into two separate cells, which are not always similar to each other. Second, the cell enlargement, one or both of the daughter cells enlarges in volume. The last is differentiation, where cells that have reached volume eventually become specialized in a certain way. Following these stages, in which cells divide, enlarge, and specialize have generated various types of plant tissues and organs, as well as many forms of plants.

The cell enlargement itself is the absorption process of water into the expanding vacuole, then stretching the cell wall. In this process, the driving force for growth is turgor pressure. The pressure inside the cell is due to the mechanical resistance of the cell wall to stretching. If this resistance is reduced then the wall is relaxed. The water potential decreases and the potential gradient of the water will increase, then the water will move into the cell causing an increase in the cell [18].

\subsection{Terpenoid content}

Histochemical assay of the $3^{\text {rd }}$ and $6^{\text {th }}$ leaf terpenoid compounds showed positive in the presence of brownishyellow color in the vascular bundles, epidermis, and oil glands. (Figures 4 and 5).

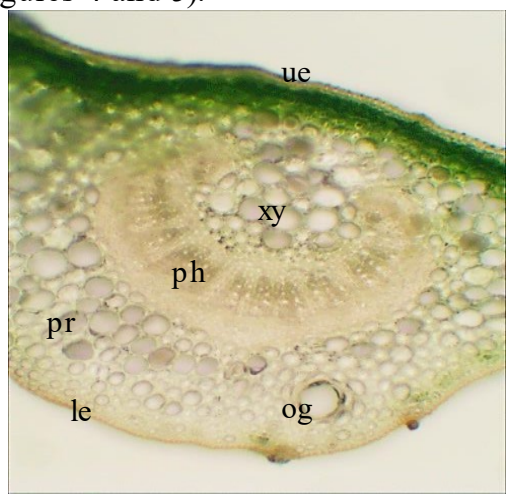

Figure 4. Cross-section of midrib E. suaveolens leaves before staining, at a magnification of $x$ 520. Note : upper epidermis (ua), phloem (ph), xylem (xy), abaxial epidermis (le), parenchyma (pr), oil gland (og).

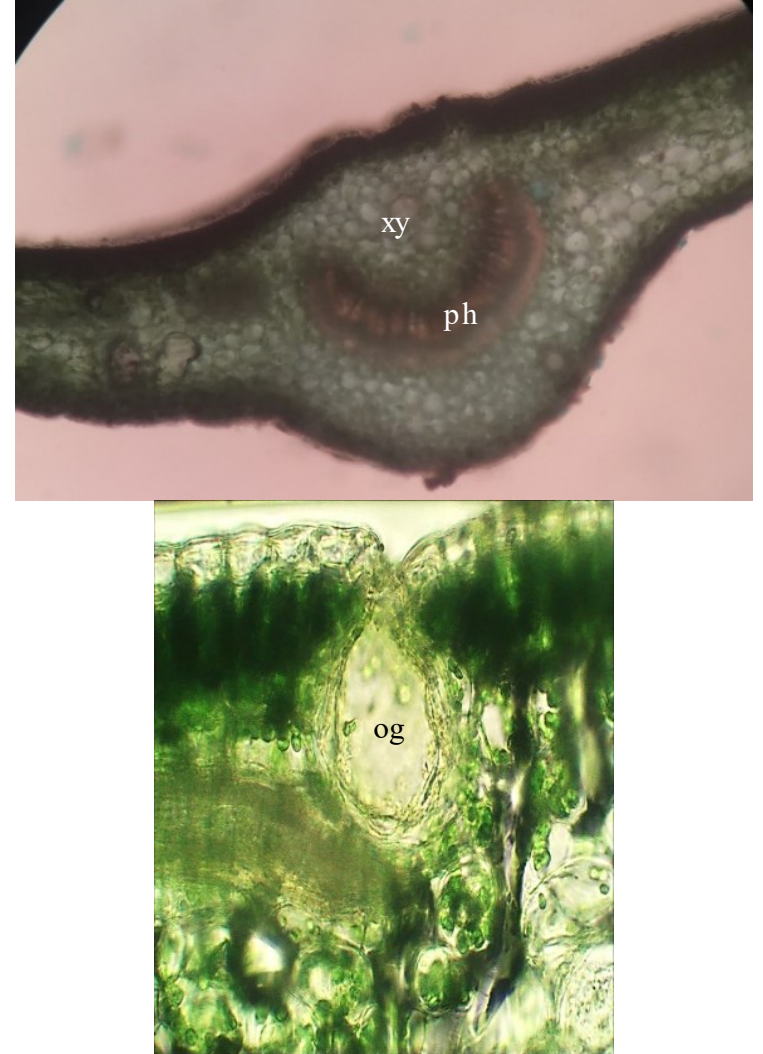

Figure 4. After staining with copper acetate A). Cross-section of midrib 3rd E. suaveolens Leaves, terpenoid is a vascular bundle, oil gland and epidermis showed brownish yellow color, at a magnification of $x 100$. B). Terpenoid in the oil gland showed brownish-yellow color, at a magnification of $\mathrm{x} 400$. Oil gland $(\mathrm{og})$.

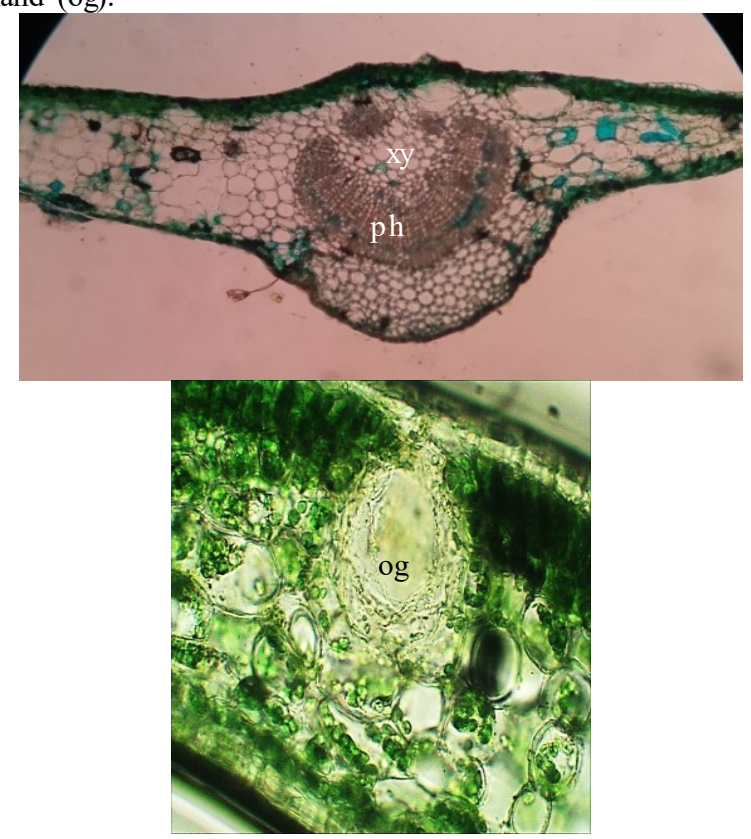

Figure 5. After staining with copper acetate A). Cross-section of midrib 6th E. suaveolens Leaves, terpenoid is in a vascular bundle, oil gland, and epidermis showed brownish yellow color, at a magnification of $x 100$. B). Terpenoid in the oil gland showed brownish yellow color, at a magnification of $x 400$. Oil gland $(\mathrm{og})$. 
The leaves of E. suaveolens contain essential oils, with a very characteristic aroma. According to [19], this substance is terpenoids found in the vaporized fraction, commonly referred to as «atsiri» (Indonesian). This substance causes the release of a special aroma in various plants as well, and anatomically produced in glandular cells in plant tissues Zodia has an oil gland shape that is similar to the oil glands in the leaf petioles of Citrus and the fruit skin of Citrus liriodendron [20].

\section{Conclusion}

1. Cross-section of zodia leaves composed of upper and lower epidermis, where stomata are located in both epidermises. Mesophyll consisting of palisade and sponges. The diameter of the oil gland is greater in the 6th leaf, while the density does not differ in the 3 rd and 6th leaves. The oil glands in mesophyll are underneath both epidermis es.

2. Terpenoids on the 3rd and 6th leaves are positive in the vascular bundles, oil glands, and epidermis.

\section{References}

4. Mustamir, Rosnani. Isolasi Seyawa Bioaktif Penolak (Repellent) Nyamuk dari Ekstrak Aseton Batang Tumbuhan Legundi (Vitex trifolia). J. Bul. Lit.. XIX, 174-180, (2008)

5. E. Yuniarsih, E. Uji Efektivitas Losion Repelan Minyak Mimba Azadirachta indica A. Juss) terhadap Nyamuk Aedes aegypti. Skripsi Program Studi Farmasi Fakultas Kedokteran dan Ilmu Kesehatan, Universitas Islam Negeri (UIN) Syarif Hidayatullah, Jakarta, (2010)

6. E.P Astuti, A. Riyadhi, N.R. AhmadiEfektivitas Minyak Jarak Pagar sebagai Larvasida, AntiOviposisi dan Ovisida terhadap Larva Nyamuk Aedes albopictus. J. Bul. Lit. 22, 44-53, (2011)

7. M. Firdaussi, Gita. Uji Aktivitas Antimalaria Isolat Terpenoid Ekstrak Etanol Daun Kembang Bulan (Tithonia diversifolia) pada Mencit yang Diinfeksi Plasmodium berghei. Skripsi Fakultas Farmasi, Universitas Jember, Jember, (2013)

8. A.P.Verawati, K.P Anam, D. Kusrini. Identifikasi Kandungan Kimia Ekstrak Etanol Serai Bumbu (Andropogon citratus D.C) dan Uji Efektivitas Repelen terhadap Nyamuk Aedes aegypti. J.1 Sains dan Mat. 21, 20-24,(2013)
9. R.C. Rachmawati, R. Rurini, U.P. Juswono. Isolasi Minyak Atsiri Kenanga (Cananga odorata) Menggunakan Metode Distilasi Uap Termodifikasi dan Karakterisasinya Berdasarkan Sifat Fisik dan KG-SM. Kim. Stdn.J. 1, 276-282 (2013)

10. L. Zabida. Uji Daya Repellent Minyak Atsiri Zodia (Evodia suaveolens Scheff), Selasih (Ocimum spp.) dan Lavender (Lavandula latifolia Chaix) pada Nyamuk. Universitas Islam Negeri Malang, Malang, (2006)

11. M.A.A. Sianipar. Kemampuan Ekstrak Daun Zodia sebagai Repellent Nyamuk Aedes aegypti Berdasarkan Lama Penggunannya. Universitas Sumatera Utara, Medan, (2010)

12. L. Susanti, H. Boesri. Toksisitas Biolarvasida Ekstrak Tembakau dibandingkan dengan Ekstrak Zodia terhadap Jentik Vektor Demam Berdarah Dengeu (Aedes Aegypti). Bul. Pen. Kes. 40,75-84, (2012)

13. R. Renaninggalih, KY Mulkiya, E.R. Sadiyah. Karakterisasi dan Pengujian Aktivitas Penolak Nyamuk Minyak Atsiri Daun Kecombrang (Etlingera elatior Jack) R.M Smith). Prosiding SnaPP 2014 Sains, (2014)

14. Muhamat, Hidayaturrahmah. Penampakan Morphologi Kulit Luar Marmut terhadap Pemberian Minyak Atsiri Tanaman Zodia secara Rutin. J. Biosp. 7, 47-52, (2014)

15. S.E. Ruzin. Plant Microtechnique and Microscopy. Oxford University Press, Oxford, (1999)

16. J.D. Bancroft. Histochemical Techniques. Butterworths \& Co (Publishers) Ltd, London, (1975)

17. S. Khatun, C. Ugur, C.N. Chandra. Phytochemical Constituents Vis-a-Vis Histochemical Localization of Forskolin in a Medicinal Plant Coleus forskohlii Briq. J. of Med. Pl Resch. 5, 711-718, (2011)

18. S. Sharma, Richa, Harsimran. Phytochemical and anatomical screening of Ecliptca prostrata L. an important medical herb from Chandigarh. $\mathrm{J} \mathrm{Med} \mathrm{Pl}$ Stud 5, 255-258, (2017)

19. D.J. King, R.M. Gleadow, I.E. Woodrow. Regulation of Oil Accumulation in Single Glands of Eucalyptus polybractea. J. Comp. 172, 440-451 (2006)

20. E.B Hidayat. Anatomi Tumbuhan Berbiji. ITB Bandung, (1995)

21. F.B. Salisbury, C.W. Ross. Fisiologi Tumbuhan. Jilid 2. Penerbit ITB. Bandung, (1995)

22. Harborne. Metode Fitokimia. ITB, Bandung, (1996)

A. Fahn. Anatomi Tumbuhan. Edisi Ketiga. Gadjah Mada University Press, Yogyakarta, (1991) 